\title{
Microstructure optimization of alumina/zirconia materials resistant for abrasive wear
}

\author{
Optymalizacja mikrostruktury materiałów korundowo-cyrkoniowych \\ odpornych na zużycie abrazyjne
}

\author{
ZBIGNIEW PĘDZICH \\ AGNIESZKA WOJTECZKO *
}

DOI: 10.17814/mechanik.2016.5-6.55

Międzynarodowa Konferencja IMT 2016
Sintered particulate composites in corundum-tetragonal zirconia system are the group of materials often utilized as structural ceramics because of their relatively low cost and high level of mechanical properties. In the paper results of experiment correlating basic mechanical (strength, fracture toughness) and useful (abrasive wear resistance, subcritical crack growth) parameters with composites microstructure were presented. KEYWORDS: corundum, tetragonal zirconia, microstructure, wear resistance

Spiekane kompozyty ziarniste w układzie korundtetragonalne polikryształy dwutlenku cyrkonu są grupą materiałów czesto stosowana jako ceramika konstrukcyjna, ze względu na stosunkowo niską cenę oraz dobry poziom właściwości mechanicznych. W pracy przedstawiono wyniki eksperymentu korelującego podstawowe parametry mechaniczne (wytrzymałość, odporność na kruche pękanie) oraz użytkowe (odporność na zużycie ścierne, odporność na pękanie podkrytyczne) z mikrostruktura tworzyw kompozytowych.

SŁOWA KLUCZOWE: korund, dwutlenek cyrkonu, mikrostruktura, odporność na ścieranie

The exploitation of many mechanical devices consists in the movement of different parts which are very often exposed to the action of loose hard particles. This may cause many problems due to destruction of surface quality and tightness of part connections. The intensive wear rate in relatively small areas could destroy even large and complicated devices. Ceramic materials are very promising from this point of view. Alumina and tetragonal zirconia sintered bodies are the most popular oxide materials due to their relatively good properties correlated with reasonable costs of manufacturing. The composites in alumina-zirconia system have been widely investigated for many years in many

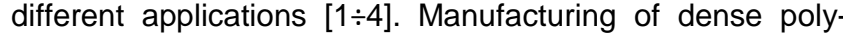
crystalline sintered products using the phases with different coefficients of thermal expansion (CTE) led to generation of thermal residual stresses which were built up during cool-

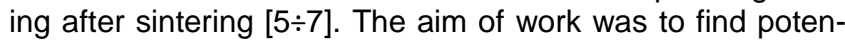
tial correlation between some parameters of sintered alumina-zirconia polycrystals, like strength, fracture toughness or subcritical crack susceptibility and wear resistance.

\section{Materials and methods}

- Samples preparation. The samples for investigations were prepared from commercial alumina (TAIMEI Chemi-

\footnotetext{
* Dr hab. inż. Zbigniew Pędzich, prof. AGH (pedzich@agh.edu.pl), mgr inż. Agnieszka Wojteczko - Katedra Ceramiki i Materiałów Ogniotrwałych, Wydział Inżynierii Materiałowej i Ceramiki, Akademia Górniczo-Hutnicza
}

cals, TM-DAR) and zirconia (TOSOH, TZ-3Y) powders.

The general idea of composite designing was to produce materials with different types of microstructures. Four composite materials were planned - material with isolated inclusions (AZ05) containing 5 vol.\% of zirconia, material with inclusions content near the percolation point (AZ15) containing 15 vol.\% of zirconia and two materials with two continuous interpenetrating phases (AZ35, AZ50) containing 35 and $50 \mathrm{vol}$ \% of zirconia, respectively. Monophase alumina was used as a reference material. Composite powders were prepared by wet (isopropanol) mixing of alumina and zirconia powders in the considered proportion in the atrittor for 30 minutes using $2 \mathrm{~mm}$ zirconia grinding media. Consequently, the samples were formed by uniaxial pressing (50 MPa) and then isostatically re-pressed under pressure of $300 \mathrm{MPa}$.

Monophase alumina (corundum - A) and AZ05 material were both sintered at $1400^{\circ} \mathrm{C}$. Other samples AZ15, AZ35 and AZ50 were sintered at $1500^{\circ} \mathrm{C}$. In both cases soaking time at maximum temperature was 2 hours (with temperature increase rate $3^{\circ} \mathrm{C} / \mathrm{min}$.).

\section{Results and discussion}

- Samples characteristics. All data concerning sample characteristic were collected in the table. Density of sintered bodies was measured by Archimedes method at $21^{\circ} \mathrm{C}$. Relative density $\left(d_{\text {rel }}\right)$ was determined by the reference of measured density to the theoretical value (assuming that alumina density is $3.99 \mathrm{~g} / \mathrm{cm}^{3}$ and zirconia density is $\left.6.10 \mathrm{~g} / \mathrm{cm}^{3}\right)$.

Fracture toughness of materials was determined by three-point bending test of bars with notch, according to [8] standard.

Abrasive wear susceptibility under the Dry Sand Test [9] conditions was determined using the abrasive medium silicon carbide powder ( $\mathrm{SiC} 80$ ) with the grain size range of $160 \div 200 \mu \mathrm{m}$. The number of rotations of the rubber wheel during each test was 2000. Two different samples were tested for each material type. The temperature during the test was $20^{\circ} \mathrm{C}$. Wear rate was determined as the volume of the sample loss $\left(\Delta V\right.$ in $\left.\mathrm{mm}^{3}\right)$.

Bending stress $(\sigma)$ measurements were made utilizing biaxial loading test [10]. Sampled had about $14 \mathrm{~mm}$ in diameter and $1.2 \mathrm{~mm}$ of thickness. Environmental conditions were: temperature $20^{\circ} \mathrm{C}$ and humidity in the range of $42 \div 55 \%$ ). Biaxial loading experiment was made at four stress rates: $0.1,1,10$ and $200 \mathrm{MPa} / \mathrm{s}$. To gain high statistical confidence, thirty experiments for each stress rate were made [11]. These measurements, known as Constant Stress Rate Test [12] allowed us to calculate parameter $n$ which could be taken as a measure of slow crack propagation susceptibility. The higher is the $n$ value, the lower is the slow crack propagation susceptibility. 
Microstructure observation was made using scanning electron microscope Nova Nano SEM 200.

\section{TABLE . Properties of investigated materials}

\begin{tabular}{|c|c|c|c|c|c|}
\hline Sp. & $\begin{array}{c}d_{\text {rel, }} \\
\%\end{array}$ & $\begin{array}{c}K_{l c}, \\
\mathrm{MPa} \mathrm{m}^{0.5}\end{array}$ & $\begin{array}{c}\sigma, \\
\mathrm{MPa}\end{array}$ & $\begin{array}{c}n, \\
-\end{array}$ & $\begin{array}{c}\Delta V, \\
\mathrm{~mm}^{3}\end{array}$ \\
\hline $\mathrm{Al}_{2} \mathrm{O}_{3}$ & $\begin{array}{c}99.28 \\
\pm 0.05\end{array}$ & $\begin{array}{c}4.34 \\
\pm 0.20\end{array}$ & $\begin{array}{c}413.04 \\
\pm 103.35\end{array}$ & 21.83 & $\begin{array}{c}11.98 \\
\pm 2.44\end{array}$ \\
\hline $\mathrm{AZ5}$ & $\begin{array}{c}98.55 \\
\pm 0.36\end{array}$ & $\begin{array}{c}4.83 \\
\pm 0.40\end{array}$ & $\begin{array}{c}561.14 \\
\pm 67.60\end{array}$ & 56.08 & $\begin{array}{c}4.86 \\
\pm 0.47\end{array}$ \\
\hline $\mathrm{AZ15}$ & 98.99 & $\begin{array}{c}5.88 \\
\pm 0.20\end{array}$ & $\begin{array}{c}722.36 \\
\pm 79.08\end{array}$ & 75.22 & $\begin{array}{c}3.14 \\
\pm 0.74\end{array}$ \\
\hline $\mathrm{AZ35}$ & $\begin{array}{c}99.04 \\
\pm 0.30\end{array}$ & $\begin{array}{c}4.84 \\
\pm 0.34\end{array}$ & $\begin{array}{c}780.61 \\
\pm 106.25\end{array}$ & 60.73 & $\begin{array}{c}2.28 \\
\pm 0.09\end{array}$ \\
\hline $\mathrm{AZ50}$ & 98.96 & $\begin{array}{c}6.57 \\
\pm 0.11\end{array}$ & $\begin{array}{c}907.87 \\
\pm 135.64\end{array}$ & 61.50 & $\begin{array}{c}2.44 \\
\pm 0.23\end{array}$ \\
\hline
\end{tabular}
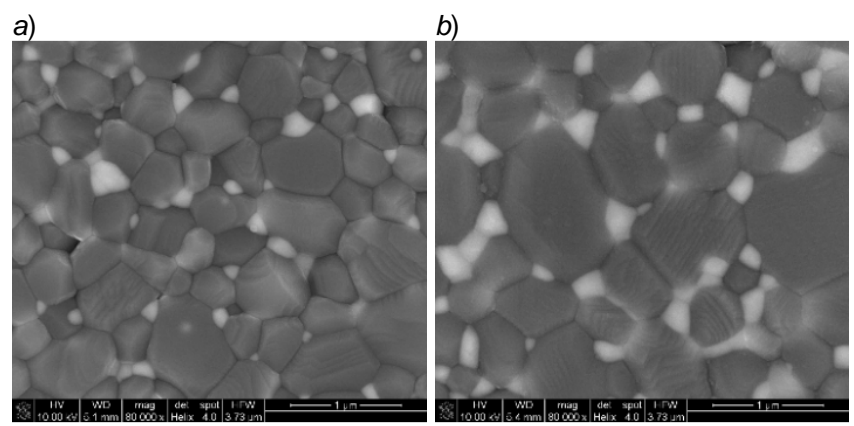

c)

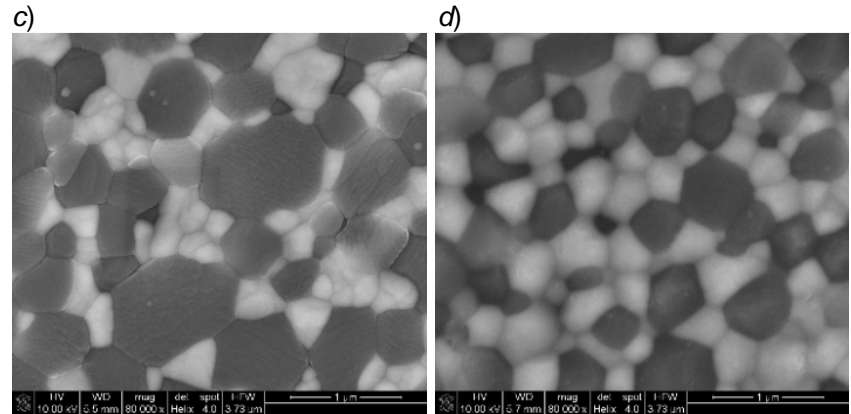

Fig. 1. Microstructures of sintered composites: a) AZ05, b) AZ15, c) AZ35, d) AZ50. Gray grains - alumina phase, light grains - zirconia ones. Marker bar indicates $1 \mu \mathrm{m}$

All investigated samples were well densified (>98.5\% of theoretical density). This allowed us to compare results of others performed tests as reasonable and representative for material properties.

Fracture toughness of composites was generally higher than fracture toughness of alumina. Dependance of $K_{l c}$ parameter on zirconia content is not monotonic. Maximal values were detected for AZ15 and AZ50 materials. The first case (AZ15) was the material with zirconia grains near the percolation point. In such material compressive residual stresses in alumina, came from high thermal expansion coefficient of zirconia, acted the most effectively. The second case (AZ50) was in fact a material with equal amount of alumina and zirconia. In this material the influence of zirconia fracture toughness on composite properties was the highest. This was the reason of very high $K_{/ c}$ value of this material.

Bending strength $(\sigma)$ of investigated materials changes in monotonic way. Any addition of zirconia phase caused strength increase. This increase was the higher, the higher was the zirconia phase amount.

Subcritical crack growth resistance (as a revers of susceptibility) expressed as the high value of $n$ parameter (see table) for all composites was much better than for the pure corundum phase. A distinct maximum of $n$ existed for AZ15 material. In this material it is connected with residual stress- es distribution. Their influence was similar to influence on $K_{l c}$ value.

Wear resistance of all composites was also much better than wear resistance of corundum. The amount of zirconia in the material was decisive form the level of this property improvement. Results of wear test was not correlated with $K_{l c}$ or $n$ values.

\section{Summary}

Investigation of wear resistance of alumina-zirconia materials in a wide range of composition, performed under dry sand test conditions, showed that the best properties have the materials with duplex structure.

There was no simply relation between fracture toughness, bending strength or resistance for subcritical crack growth and wear rate. Mentioned basic parameters $\left(K_{l c}, \sigma, n\right)$ were much more fragile on microstructural aspects, but the simple statement that the higher was zirconia amount, the higher was the wear resistance, wasn't the true. AZ35 and AZ50 materials showed practically the same value of $\Delta V$. From the technological and economical point of view the AZ35 material is easier for manufacturing and cheaper.

This work was made with financial support of the Polish State Ministry of Science and Higher Education under grant no. AGH 11.11.160.617. Support was also given from the Polish Ceramic Society. The authors thank to the PhD Eng. M. Ziąbka for executing SEM observations.

\section{LITERATURE}

1. Nevarez-Rascon A., Aguilar-Elguezabal A., Orrantia E., Bocanegra-Bernal M.H. „On the wide range of mechanical properties of ZTA and ATZ based dental ceramic composites by varying the $\mathrm{Al}_{2} \mathrm{O}_{3}$ and $\mathrm{ZrO}_{2}$ content". International Journal of Refractory Metals \& Hard Materials. Vol. 27, No. 6 (2009): pp. 962 $\div 970$.

2. Naglieri V., Palmero P., Montanaro L., Chevalier J. „Elaboration of Alumina-Zirconia Composites: Role of the Zirconia Content on the Microstructure and Mechanical Properties". Materials. Vol. 6, No. 5 (2013): pp. 2090-2102.

3. Sá e Benevides de Moraes M.C. C. [de], Elias C. N., Filho J. D., Guimarães de Oliveira L. „Mechanical properties of aluminazirconia composites for ceramic abutments". Materials Research. Vol. 7, No. 4 (2004): pp. 643 $\div 649$.

4. Marro F. G., Palomero P., Kern F., Mastro A. „Processing of alumina-zirconia composites by surface modification route with enhanced hardness and wear resistance". Ceramics International. Vol. 41, No. 1 (2015): 889 $\div 898$.

5. Cesari F., Esposito L., Furgiuele F.M., Maletta C.,Tucci A. „Fracture toughness of alumina-zirconia composites”. Ceramics International. Vol. 32, No. 3 (2006): pp. 249-255.

6. Grabowski G., Peedzich Z. „Residual stresses in particulate composites with alumina and zirconia matrices". Journal of the European Ceramic Society. Vol. 27, No. 2-3 (2007): pp. $1287 \div 1292$.

7. Pędzich Z. „Fracture of oxide matrix composites with different phase arrangement". Fractography of Advanced Ceramics III

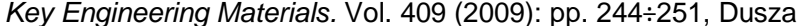
J., Danzer R., Morrell R., Quinn G.D. (Eds.), Trans Tech Publications Inc., Switzerland.

8. ASTM C1421-10, Standard Test Methods for Determination of Fracture Toughness of Advanced Ceramics at Ambient Temperature, (2010).

9. ASTM G65-94 Standard: Test Method for Measuring Abrasion Using the Dry Sand/Rubber Wheel Apparatus, (1994).

10. ASTM F394-78 Standard: Test Method for Biaxial Flexure Strength (Modulus of Rupture) of Ceramic Substrates, (1996).

11. ASTM C1161-02c, Standard Test Method for Flexural Strength of Advances Ceramics at Ambient Temperature, (2002).

12. ASTM C1368-06, Standard Test Method for Determination of Slow Crack Growth Parameters of Advanced Ceramics by Constant Stress-Rate Flexural Testing at Ambient Temperature, (2006). 